\title{
Entelektüel Elden Bağımlı Ele: Deneyimin Müsaderesi ${ }^{\star}$
}

\author{
O. Özgür Güven**
}

\section{Öz}

Bu çalışmada, kullanıcı emeği elin toplumsal evriminin bir kesiti üzerinden tartışılıyor. Yaratıcı yaşamsal etkinliğin sembolü olagelen el, insanın biyolojik ve kültürel evriminde kritik bir öneme sahip. Düşünme, "kavramak" fiilinin ikili anlamından da anlaşılacağı üzere, bir kimsenin tuttuğu şeyin doğası etrafında ortaya çıkar. Bu açıdan seri üretim kitap, elin dünyayla benzersiz ilişkisinde bir dönüşüm evresini temsil eder. Birörnek kitap, dünyayı elde tutulan bir deneyim olarak yeniden kuran ilk teknolojidir. Bu deneyimin, günümüzün dijital dünyasındaki aracısı ise kuşkusuz akıllı mobil telefondur. Mobil telefonun baskın kullanımı, etkinliğini performatif bir işleve indirgediği elin içsel paradokslarını derinleştiren sonuçlara yol açıyor. İletişim ve kültür teknolojilerinin ortaya çıkardığı günümüz endüstri sonrası toplumunda çalışma, üretken her öznenin bir etkinlik biçimi olarak yeniden tanımlanıyor. Bu noktada mobil telefon, eli manipüle eden kompakt bir deneyimle kullanıcı emeğini üretim süreçlerine katıyor. Dolayısıyla mobil telefon, yeni teknolojilerin ve yeni işçi türlerinin ortaya çıkmasıyla karakterize edilen dijitalleşme çağında emek ve sömürü kavramlarının geleneksel tanımlarını tartışmada anlamlı bir uğrağı temsil ediyor. Meta piyasası, deneyimi pazarın ihtiyaçları doğrultusunda davranışsal veriye indirgerken, kullanıcıyı enformel bir çalışana dönüştürüyor. Her gün milyarlarca el, hiçbir emek sözleşmesine dahil olmaksızın bilgi ekonomilerine veri sağlıyor. Hiç olmadığı kadar meşgul olan el, kavramaya çalıştıkça sürgünü olduğu bir dünya deneyiminin içine düşüyor.

\footnotetext{
* Geliş tarihi: 07/01/2020 • Kabul tarihi: 10/02/2020

** Gaziantep Üniversitesi İletişim Fakültesi Radyo TV ve Sinema Bölümü.

Orcid no: 0000-0002-9927-7872, ozoguven@gmail.com
} 


\title{
From Intellectual Hands to Dependent Hands: Exploitation of Experience*
}

\author{
O. Özgür Güven ${ }^{\star *}$
}

\begin{abstract}
In this study, user labour is discussed through a section of the social evolution of hands. Hands, which are the vital symbol of creative activity, has a crucial role in human biological and cultural evolution. Thinking emerges around the nature of what one holds, as can be understood in the dual sense of the verb "to grasp". In this respect, the mass production book represents a transformation phase in the unique relationship of hands to the world. A uniform book is the first technology to rebuild the world as a hand-held experience. Undoubtedly the mediator of this experience in today's digital world is the smart mobile phone. The dominant way of using mobile phone deepens the inner paradoxes of hands by reducing their agency to a performative function. In today's post-industrial society brought about by communication and cultural technologies, work is redefined as a form of activity for every productive subject. In this regard, the phone, which manipulates hands, integrates user labour to the production processes with a compact experience. Therefore, the mobile phone represents a meaningful moment to discuss the traditional definitions of labour and exploitation in the age of digitalization which is characterized by the emergence of new technologies and new types of workers. The commodity marketplace reduces the experience to behavioural data in line with the needs of the market and turns the user into an informal employee. Every day, billions of hands provide data to information economies without being involved in any labour contract. Hands that are busier than ever become exiles of the world as they are trying to grasp it.
\end{abstract}

Keywords: Hands, experience, mobile phone, user labour, exploitation.

\footnotetext{
* Received: 07/01/2020 - Accepted: 10/02/2020

** Gaziantep University Faculty of Communication Department of Radio Television and Cinema.

Orcid id: 0000-0002-9927-7872, ozoguven@gmail.com
} 


\section{Entelektüel Elden Bağımlı Ele: Deneyimin Müsaderesi}

İnsanları ölümlü hayatlarının ötesine taşıyan buluşların mucidi el, yaratıcı yaşamsal etkinliğin sembolü olageldi. Tohum eken, yün eğiren, yemek pişiren, duvar yapan, kitap sayfası çeviren, kalem tutan el; bitimsiz etkinliğiyle hep meşgul oldu ve yordamıyla her seferinde başka yaşamsal anlamlar üretti. Charles Darwin (2004: 71-75), evrim sürecinde el ve kol kullanmanın maymunlarda beyin büyümesine yol açtığı sonucuna varmıştı. El ile öğrenme arasındaki bu ilişkiyi Richard Sennett (2019: 192), insanların ataları "maddeleri ellerinde tutmayı, tuttukları şeyler hakkında düşünmeyi ve nihayet tuttukları şeyleri şekillendirmeyi öğrendiler; insan-maymunlar alet yaptılar, insanlar ise kültür yaptılar” şeklinde açıklıyor. Karl Marx (1993: 706), insan iradesinin doğaya iştiraki olarak gördüğü makineleri "insan eli tarafından yaratılan insan beyninin organları" (vurgu orijinal) şeklinde tasvir ediyor. Hannah Arendt (1998) ise insanları doğal süreçlerin yıkıcı sonuçlarından koruyan ve onların ölümlü hayatlarına istikrarlı bir kalıcılık sağlayan şeyin homo faberin özgürce kullandığı elleri olduğunu söylüyor. Gözkapaklarının istemsiz hareketlerinin tersine, tutma eyleminin gönüllü bir hareket ve bir karar olduğuna vurgu yapan Sennett'e göre (2019: 193-194), düşünme bir kimsenin tuttuğu şeyin doğası etrafında ortaya çıkar. Dolayısıyla, "ele almak" ifadesinin zihinsel bir süreci anlatması; bir meseleye dair "elle tutulur bir tarafı yok" ifadesinin bir yargıуı içermesi; "bir şeyi kavradığını" söylemenin hem fiziksel bir el hareketini hem de bir şeyi anlamayı ifade etmesi gibi tüm bu haller esasen evrim sürecinde el ile beyin arasındaki diyaloğu yansıtır.

El, insanın biyolojik evriminde olduğu gibi kültürel evriminde de kritik bir öneme sahip. Baş edebilmek için doğaya müdahale eden el, medeniyet inşa eden/yıkan aletler yaptı. Tanrıya yakardı, yurttaşılık görevi için oy kullandı. Teslim olmak için havaya kalktı, kavgada yumruk oldu. Tanımak için sıkılan el, tutulan ele aşkı ifade etti... Dolayısıyla el, beyinle diyaloğunda bedenle ilişkisini teyit ederken, deneyimin bedenin dışına taşan toplumsal bilgisini (soyut genellik) üretir. Dünya ile ilişkimizin esasını belirleyen el, geleneksel ölçü birimidir aynı zamanda. Maurizio Ferraris (2014: 30), nesnelerin istikrarını belirleyen ekolojik sınırın "ele yatkınlık" ilkesine dayandığını söylerken, toplumsal geometrinin el tarafından ve el etrafında örgütlendiğine işaret eder. 
Bugün, kim olduğumuzdan nasıl ilişki kurduğumuza kadar pek çok toplumsal süreci radikal bir şekilde etkileyen bir dijital dönüşüm yaşanıyor. İnternet, akıllı mobil telefonlar, veri tabanları, otomasyon teknolojileri, büyük veri analitiği, yapay zeka, kişisel bilgisayarlar, coğrafi bilgi sistemleri, sosyal medya, bulut tabanlı bilişim vb. dijital teknolojilerin etki ettiği toplumsallıkta; gündelik karşılaşmalar yeniden kurulurken, zaman ve mekanın geleneksel sınırları alt-üst oluyor. Dolayısıyla, dijitalleşmeyle dünyanın farklı bir yer haline geldiği, günümüzün güncel tartışmalarındandır. Tartışma konusu olan bu dünyanın, benzeri görülmemiş bir ölçekte tekilliklerin elbirliğiyle inşası ise bu çalışmanın sorunsalıdır. Aşağıdaki tartışma, sermaye birikim rejimi tarafından yönlendirilen dijitalleşme süreçlerinin dünyayla ilişkimizi anlamlandıran elin etkinliğini ve çalışmayı nasıl dönüştürdüğü sorusuna yanıt arıyor.

Mobil telefonla her an temasta olan milyarlarca el, dünyanın dijitalleşmesinde genişletilmiş bir faaliyet alanını ifade ediyor. Meta piyasasının yön verdiği bu faaliyet, el ile beyin arasındaki diyalogu sekteye uğratıyor. Dijital ekran tarafından kolonize edilen el, manipüle edilmiş etkinliğiyle zihinsel süreçler hilafına bir performans sergiliyor. Mobil telefonla temasında, gündelik somut karşılaşmaları ve materyal deneyimleri giderek minimize eden el; dijitalleştirdikçe ilgisini kaybettiği dünyayla bağı çözülen bir öznellik inşa ediyor. Söz konusu öznelliğin aldığı görünümleri ele alan bu çalışmada, ilk olarak, birörnek kitapla ortaya çıktığı savunulan elde tutulan dünya deneyimi inceleniyor. Devamında, seri üretim kitabın öncülük ettiği türdeşlik paradigmasının piyasasını kurduğu elde tutulan dünya deneyiminin, mobil telefonun ortaya çıkmasıyla birlikte aldığı hegemonik görünümler tartışılıyor. Ardından, gelişen iletişim ve kültür teknolojilerinin, konum ve biçimleriyle çalışmaya etkileri ve dijital emek süreçlerinin sosyo-ekonomik dinamikleri analiz ediliyor. Bu kavramsal çerçeveden hareketle; kullanıcı emeğinin genişleyen piyasalardaki müsaderesi, davranışsal verilere indirgenen deneyim tartışması üzerinden inceleniyor.

\section{Elde Tutulan Dünya: Kitap}

Pek çok sarsıcı toplumsal dönüşüm dinamiğine kaynaklık eden matbaa, nesnelerle karşılaşma deneyimimizi radikal bir biçimde etkiledi. Matbaa, standardize edilmek suretiyle kitlesel seri üretimi yapılan ilk sanayi ürünü kitabı mümkün kıldı (McLuhan, 
2014: 231). Birörnek kitap, her bir nesnenin eşsizliği bilgisinin ve her birinin bir mucidi olduğuna dair inancın altını oyan bir dönüşüm evresini temsil eder. Buradaki nesne, Benedict Anderson'un ifade ettiği gibi (2015: 49), niceliksel ölçüden ibaret bir kilo şeker veya tuzdan farklı olarak kendi içinde ayrık ve kapalı bir nesnedir. Bir kitabın (bu bir masa da olabilir) münzevi bir kendine yeterliliği vardır ve biri diğerine karışmaz. Standardize edilmiş kitap, elde taşınabilme özelliğiyle önceki biçimlerinden ayrılır. Walter Ong (1961: 167) kitabın bu formunu, düşüncenin iletişimini sağlayan sözcüklerin temsili olmaktan ziyade, sözü şeyleştiren bir eşya olarak tanımlar. Kitabın popülerleşmesinde önemli katkısı olan bu form, okuma eyleminin kişiselleşmesine yol açtı. Sükunet içinde baş başa kalınan kitap, uzam ve zamanda gerçek ya da kurmaca karşılaşmalara imkan verir. Yerel kendiliği, başka kendilik veya kolektif oluşlar hakkında ayrıntılı anlatımlarla dünyanın bilgi veya duygusuna muttali kılma iddiası her an ulaşılabilir bir mesafededir artık.

Bilginin kaynağı olduğuna inanılan el yazması, katip ile sıradan insanı ayırırken, taşınabilir birörnek kitap bu ayrıma son verdi. Kişinin malumat devşirmek için ne Orta Çağ katibinin, ne de kütüphane kurdu tutkulu filozofun eşsiz deneyimine ihtiyacı vardı. Elbette kitabın bu işlevi yerine getirebilmesi, kendiliği esas alan hakikat düşüncesinin yerini, öğrenme süreçlerinin nesnesi dışsal bir dünya bilgisine terk etmesiyle mümkün oldu. Kitabın, dünyaya açılan ve hayatın farklı suretleriyle karşılaşmayı vaat eden kapı imgesiyle anılması tesadüf değil bu yüzden. Dünyanın sınırı olan bu kapı okuryazara ardına kadar açıktır artık. Kapalı ve bitmiş teknoloji olarak kapının ardındaki dünyaya kalıcılık atfeden kitap, okura depolanmış deneyimi keşfetme isteği telkin eder. Her yeni baskısındaki olası değişiklikleri okura bildirdiğinde bile, bitmişliğine olan inancı teknoloji-toplum (altyapı-üstyapı) ilişkisi bağlamında yeniden onaylar.

Birörnek kitabın temsil ettiği simgeselliğe istikrarlı bir sürdürebilirlik sağlaması, Marshall McLuhan'ın ifadesiyle (2014: 111), okuryazarın dünyayla kopuş yaşaması ama aynı zamanda türdeş bir okuryazarlık deneyimi icat etmesiyle mümkündür. Bu açıdan seri üretim kitap, elin entelektüel evriminde dramatik bir geçişi temsil eder. Dışsal dünyayla karşılaşmayı popüler sıklık ve genişlikte elde tutulan bir deneyim biçimine dönüştüren ilk bilgi teknolojisidir kitap. Hegemomik elde tutulan dünya deneyiminin günümüzdeki baskın aracısı ise kuşkusuz dijital bir makine olan mobil telefondur. Ders verdiğim kampüsteki kitapçının gösterişli ön duvarındaki panoda yer 
alan "Kitapların şarjı hiç bitmiyor." ifadesi; Sennett'in işaret ettiği gibi (2019), düşüncenin (kitap-mobil telefon analojisi) kavranan şeyin (mobil telefon) doğası etrafında ortaya çıktığı gerçeğine tekabül eder. Rekabeti kitabın bir niteliği değil, mobil telefonun bir kusuru belirliyor. Kıyaslamanın rasyoneli ise aynı zamanda icatlar arası geçişi içselleştiren daha iyi bir deneyim vaadidir.

Ancak, söz konusu vaatse yeni teknolojinin daha avantajlı olduğu kuşku götürmez. Kitabın bilgiye erişme vaadini dijital ortama taşıyan internet/bilgisayar teknolojisiyle donatılan mobil telefon; kitap, ansiklopedi, sözlük, harita gibi içeriklere erişmeyi sağlarken, pusula ya da uçak bileti olabilme, paso ya da kredi kartı yerine geçebilme, fatura ya da vergi borcu ödeyebilme, partner ya da park yeri bulabilme özelliklerine de sahip. Yaşamın kopuk ögelerinin genişletilmiş bir dijital alanda verilere dönüştürülmesini sağlayan teknoloji, rasyonel dünya iddiasını kitapla karşılaştırılmayacak ölçüde ele sığan bir alette merkezileştiriyor. Mekansal ve zamansal sabitliklerin giderek aşındığı dijital çağda, gündelik hayatımızın anlamsal uğrakları da kökten dönüşüme uğruyor. Kim olduğumuz veya nasıl ilişki kurduğumuz, büyük ölçüde dijital teknoloji dolayımıyla karşılık bulan sorulardır artık.

\section{Diyalogdan Bağımlılığa}

Bir icat çoğu zaman onu kullanmanın becerisini de icat eder. "Kullanım talimatları" bu açıdan yol göstericidir mesela. Diğer taraftan, deneyim de kavranan aleti/nesneyi dönüştürecek bilgiyi üretir. Mucit icat ettiği aleti tasarlarken, elin fiziksel ve anatomik sınırlarını hesaba katmak zorundadır. Ancak icadının son halini hayal ettiğini söylemek zordur. Tamlığı/bitmişliği dışlayan bir ilişki olarak icat, kullananın müdahalesiyle her seferinde yeni bir form kazanır. Keserin keskin yüzünün zamanla eğim kazanmasında olduğu gibi deneyim, kullananın bilgi ve bedenini icada işlemek maksadıyla mucit ile giriştiği bir müzakeredir.

Modern pazarların ve fiyat sisteminin oluşumunu sağlayan birörnek kitap (McLuhan, 2014: 231), bireysel yaratıcılığı sekteye uğratan ilk türdeş tüketim nesnesiydi. İcat ile deneyim arasındaki diyalektik ilişkide bireysel etkinliğe müdahale eden türdeşleşme, günümüz toplum-teknoloji ilişkisinin baskın ideolojisidir. Endüstriyel üretimin türdeş nesneleriyle piyasa ideolojisinin genişleyen rekabet alanlarında 
karşılaşırız. Pek çok nesneyle karşılaşmamızın verileri ise, elimizden düşürmediğimiz telefonla temasımızdan devşiriliyor. İlk olarak 1990'lı yıllarda yaygınlaşmaya başlayan, konuşma ve mesaj gönderme işlevi gören birinci nesil tuşlu mobil telefonlar uzun süre elde tutması zahmetli bir boyut ve ağırlığa sahipti. Kısa süre sonra avuca kolaylıkla sığan boyutlarda olanları üretildi. Tek elle kullanılabilen bu telefonları, Apple marka dijital ekranlı telefonlar takip etti. 2007'de piyasaya çıkan bu telefonlar, tuşlu telefonların aksine, elin kavrama açısını giderek zorlayan ölçülerde üretilme eğiliminde. Ayrıca bu eğilimin, yaş, cinsiyet, coğrafya gibi farklılıklara göre değişen el boyutlarını hesaba katan bir tasarım hassasiyeti gösterdiğine dair bir işaret de yok. Mobil telefonları kavramada yaşanan güçlük çoğu durumda sakınımlı bir tutuş gerektiriyor. Öyle ki, muhtemel elden düşürmelere karşı geliştirilen koruyucu aksesuarlar önemli bir endüstriyi oluşturuyor. ${ }^{1}$

Bilgisayar özelliklerine sahip mobil telefonlar, her açıdan fiziksel kabiliyetleri gelişkin ve benzeri görülmemiş meşguliyette bir el talep eder. Ancak ekran tutan eller -ki bu teknolojiler çoğu zaman iki el kullanımını zorunlu kılıyor- keser tutan elin hilafına bir dönüşümü işaret ediyor. Yukarıda sözü edilen, alet ile el arasındaki diyalektik ilişkiyi sekteye uğratan meşgul el, onun eğitimine odaklanan teknolojik innovasyon ideolojisinin baskısı altındadır. Yeni tasarımlar ve devamlı surette indirilen güncellemeler elleri, tutmak için çaba sarf ettikleri dijital aletin yeni özelliklerine adapte olmaya zorlamakta. Öte yandan, ekranlar için dijital kalem kullanımına "zaten 10 tane kalemle doğuyoruz" diyerek karşı çıkan Steve Jobs'un kurucusu olduğu Apple firması başta olmak üzere, pek çok el hareketinin şirketler tarafından patentlendiğini biliyoruz (Leader, 2016: 2). Dolayısıyla, her indirmede güncellenen aynı zamanda elin hareketleridir. Elin, zaten tasarlanmış/tanımlanmış hareketleri yapması ve bunları ekranın neresinde kullanması gerektiğini keşfetmesi beklenir. Belge kaydırma, tıklama, yakınlaştırma/uzaklaştırma, çoklu dokunma gibi her biri farklı veriye ulaşmayı veya veri girmeyi sağlayan hareketlerdir bunlar.

Elektronik aletlerin düşünme işlevlerine ve insanın modern çağda yaşadığı deneyim kaybına dikkat çeken Arendt (1998: 321-322), "benzeri görülmemiş ve gelecek vaat eden bir insani faaliyet patlamasıyla başlayan modern çağın şimdiye

\footnotetext{
1 Koruyucu aparatları da kapsayan mobil teknoloji aksesuar pazarı verileri için bkz. "Dünya mobil aksesuar pazarı trendleri” Mediatrend, https://bit.ly/33AsF4o Erişim tarihi: 10.11.2019
} 
kadar bilinen en ölümcül ve en steril edilgenlikle sona erme ihtimali”nden söz ediyordu. Arendt'in işaret ettiği edilgenliğin bugün intimalden öte anlamlar içerdiğini, telefon tutan elimizle ilişkimizden biliyoruz. Etkin elin yerini alan, işlevleri standartlara ve kurallara bağlı performatif el, zihinsel ve bedensel süreçleri manipüle eden sonuçlar doğuruyor. Örneğin, her adımı dikte eden harita uygulaması (Google, Yandex, Moovit vb.) kullanımındaki gibi telefon; kullanıcı ile fiziki çevre arasında mesafe kurmak koşuluyla işlevselleşir. Çevrenin cansız ve minyatür bir modelinin kullanıldığı harita uygulamasının tekraren takibi, kullanıcıyı mekana kayıtsızlaştırır. Dijitalleştikçe ilgisini kaybettiği materyal dünyayla bağı çözülen öznellik, hakiki ilişki ihtimalleri tasfiye edilmiş uzamda simülatif bir canlandırma içinde yeniden kurulur. Bununla birlikte, elin harita uygulamasıyla meşguliyeti, ayağın belli bir tekrardan sonra bir adresi beden hafızasına işleyen etkinliğini de yerinden eder. Böylece, aşırı meşguliyeti sadece elin kendisini değil, aynı zamanda diğer bedensel etkinlikleri de manipüle eder.

Telefonla ilişkimiz giderek artan bir frekansta "bağımlılık" kavramıyla ifade ediliyor. Genişletilmiş bir patolojik alana işaret eden "bağımlılık", herhangi bir durum, kişi veya nesneyi tekrar sıklığı artan şekilde istemeyi anlatan bir saplantı halidir. Bu hal, ilgili hedefe ulaşılamadığındaysa yoksunluk belirtileri verir. Uzun süre telefon kullanmaktan kaynaklı el ve bileklerdeki ortopedik şikayet artışı, söz konusu patolojik temayı teyit eder (Özkan, 2016). Konuya psikiyatrik yaklaşımında Darian Leader (2016), elin bilinçli bir şekilde kontrol altında tutulamadığını söyler. Partnerimizin veya arkadaşımızın bize anlattıklarına odaklanacakken, mesaj gönderen, e-posta kontrol eden, sosyal medya sayfası güncelleyen bir ele sahibiz. İnsanların, ellerini dijital ekranlara dokunmaktan alıkoyamıyorlarmış gibi, telefonlarına ve tabletlerine çok fazla bağlı olmaktan şikayet ettiklerini belirten Leader, insan etkinliğinin ve tasarrufunun sembolü elin, giderek bizden kaçan bir parçamıza dönüştüğünü söyler.

Beyinle diyalogdan kaçış, elin bedenle ilişkisini tartışma konusu ediyor. George Lukacs (1972: 100) yaklaşık yüz yıl önce şu isabetli analizi yapıyordu: "Insanın nitelikleri ve yetenekleri artık kişiliğinin organik bir parçası değildir, dış dünyadaki çeşitli nesneler gibi 'sahiplenebileceği' veya 'feragat edebileceği' şeylerdir”. Bu dönüşümün insan bilincine damga vurduğunu söyleyen Lukacs insanın, nesnelleşmiş ve şeyleşmiş yeteneklerinin gördüğü işler karşısında düşüncelere dalan (contemplative) bir tutuma düştüğünü anlatır. Lukacs analizini, virtüöz analojisinden hareketle yapar. Buradaki, 
yetenekleri metalaşan piyanistin elleriyse; geri kalanı içine düşülen dalgınlıktır. Ödedikleri maliyeti, virtüöz elleri alkışlamak suretiyle mahsuplaşan yüzlerce elin terbiye edici tanıklığını anlatan bir dalgınlık. Ancak, özne ile bilincin nesnesi arasındaki "dalgın" (seyirci kalarak düşünme) ilişki virtüöz el ile beyin arasında yine de bir diyalog varsayar. Kaldı ki, Lukacs'ın (1972: 177-178) diyalektik karşıtlık analizleri takip edildiğinde dalmanın, proleter "bilinç durumuna gelen çelişki" durumunu, yani devrimci eylemin hazırlık sürecini karşıladığını görürüz.

Bizden kaçan elin gördüğü işler karşısında bugün yaşanılan, dalgınlıktan ziyade bir çeşit şaşkınlıktır. Şaşırmayı, "doğruyu, gerçeği, gerekli olanı ayıramayacak duruma gelmek" şeklinde açıklıyor Türk Dil Kurumu (TDK) sözlüğü. Bir olayı/olguyu müzakere edecek muhakeme kabiliyetinden mahrum kalma durumunu anlatan şaşkınlıktan, "dalgınlık" halinde olduğu gibi, bir "bilinç" devşirmenin olanağı yoktur bu yüzden. Burada şaşkınlık, anlık refleks değil bir eğilimdir. Bu eğilim, mütemadiyen güncellenen ekran (elde tutulan dünya) ile istikrarsız temasında tutulan ama kavranamayanın yol açtığı gerilimli kabulün yansımasıdır. Dünyayı kavramak için etkinliğini artıran el, müsadere edilmiş muhtemel hareketleriye tuttuğu ekranın taleplerini karşılarken dünyayla ilişkisini koparmak zorundadır. Meşgul el çelişkisinin yol açtığı bu şaşkın durum, kişinin varlığını teyit eden bir performans biçimidir aynı zamanda. Uçuruma yuvarlanan kadının cep telefonu bulunmadan kurtarılmayı ret etmesi (Birgün, 2019) öznenin meşgul ele indirgenmesinin varoluşsal komplikasyonudur.

Bu noktada Ferraris (2014), telefonun ontolojik manada ne tür bir nesne olduğunun felsefik ilginçliğini sorgular. Ferraris, mobil telefonların gündelik faaliyetleri dönüştürücü etkisinin ötesinde, toplumsal gerçekliği inşa edici niteliklerini tartışır. Mobil telefonun, ev telefonundan (kablolu ve sabit) farklı bir zuhur etme (dasein) biçimine yol açtığını söyleyen Ferraris'e göre, kimse kimsenin mobil telefonuna -ilkesel olarakcevap veremez. Çünkü mobil telefon sadece kişinindir, tıpkı ölüm gibi hep onunladır ve ölüm kadar şahsi bir nesnedir $(2014: 18,19)$. Hatta, erişimi sınırlandıran güvenlik kodları düşünüldüğünde, mobil telefonun teknolojik varlığının sahibinin ölümüyle son bulduğu söylenebilir. Mobil telefonun şahsiliği, nerede olursanız olun arandığınızda sadece sizi bulmak isteyen katıksız bir beklentiye dayanır. Telefonun kapalı olması ya da gelen çağrıya cevap vermeme durumu da bir anlam ifade eder: Duştasınız, derstesiniz, küstünüz, kaza geçirdiniz daha da kötüsü belki de öldünüz. Her an 
ulaşılabilme normunun ihlali "geçerli" bir nedene ihtiyaç duyar. Mevcudiyetin spekülatif anlamlarını üreten bu neden, fiziki ya da duygusal bir tıkılıp kalma ihtimaline dayanır. Esnekliği yadsıdığı için tekinsiz olan bu hal, mobil telefonda mütemadiyen tekrarlanan "Neredesin?" sorusuyla dışlanır.

Mobil telefona ilişik benlikten devşirilen esneklik, kişisel veya sosyal bir ilişkilenme(me) halinin ötesinde geniş sosyo-ekonomik bir bağlamın konusu esasen. Esneklik, toplumsal ve ekonomik bir inşa olarak; piyasa tabanlı kurumsal değişimlerin yön verdiği günümüz post-endüstriyel rejimin üretim, tüketim, emek süreçleri ve işgücü piyasaları dinamiklerini anlamaya dönük tartışmaların merkezinde yer alıyor (Lazzarato, 1996; Hardt ve Negri, 2004; Castells, 2008; Virno, 2013; Fuchs ve Chandler, 2019).

\section{Sosyal Fabrika: Çalışmanın Dijitalleşmesi}

Marksist analizlerde sömürü, kapitalistlerle işçilerin mülkiyet rejimi düzenlemeleri doğrultusundaki çıkar karşıtlığına odaklanarak, sınıf iktidarını ve imtiyazlarını açıklayan anahtar bir kavramdır. Geleneksel Marksist yaklaşım, sömürünün üretim araçlarının kapitalist sınıfın mülkiyetinde olmasından kaynaklandığını söyler. Kapitalistle arasında bir emek sözleşmesi olsa da işçi, üretim araçlarına sahip olmadığından hayatta kalmak için çalışmak zorundadır. Çalışmak, örgütlü bir kamusallık gerektirir. Marx (1997: 320-322), bu örgütlü kamusallığı "elbirliği” olarak adlandırır. Fabrikadaki/işyerindeki elbirliği, ücreti ödenmeyen artık emeğin yarattığı artı-değerin sermaye birikim rejimine aktarılmasıyla sonuçlanır. Kapitalist sömürünün bu mantığı kolayca bir tarafa bırakılamaz. Ancak, post-fordizmin esnekliği esas alan yöntemlerinin, fabrikanın ve geleneksel çalışan sınıfın altını oyması, sömürüye dair geleneksel Marksist yaklaşımı da tartışma konusu ediyor. Dijital ekonomilerin başat konuma geldiği günümüzde, emek, kültür, üretim ve tüketimin belli sınırlara dayalı ayrımlarından elde edilen analiz temalarının meşruiyeti sorgulanıyor. Manuel Castells (2008), günümüz kapitalist birikim rejiminin işleyişinde; enerji kaynakları bulma veya sevk etme şeklindeki endüstriyel gelişme tarzından, enformasyonel gelişme tarzına bir geçiş olduğunu söyler. Özgül bir toplumsal örgütlenmeye dayalı enformasyonel gelişme tarzının ana verimlilik kaynağı bilgi üretme, işleme ve iletişimdir. Dolayısıyla, özne/nesne, devlet/toplum, siyaset/ekonomi, kamu/özel, tüketim/üretim, 
zaman/mekan, zihin/beden, emek/boş zaman, kültür/doğa, insan/insan sonrası gibi geleneksel modern ikilikleri sarsan ve politika olanaklarını kökten değiştirdiği ifade edilen bir "dijital dönüşüm”ün (digital turn) ortaya çıktığı, günümüz sosyal bilimlerin güncel tartışma konularındandır (Fuchs ve Chandler, 2019).

“Dijital ekonomi” terimi, bir yandan medya, üniversite ve sanat gibi post-modern kültür ekonomisi (medya, üniversite ve sanat) diğer yandan enformasyon endüstrisiyle (enformasyon ve iletişim kompleksi) kesişen bir oluşumu tanımlıyor (Terranova, 2000: 35). Bu oluşum, Richard Barbrook'un ifadesiyle (2002: 135), yeni teknolojilerin ve yeni işçi türlerinin ortaya çıkmasıyla karakterize edilir. Bu bağlamda, otonomist Marksistlerin çalışmalarından elde edilen fikirler, dijital ekonominin dinamiklerini açıklamada anlamlı uğraklar sağlıyor. Otonomistler, iletişim ve kültür teknolojilerinin ortaya çıkardığı yeni toplumsal durumu "sosyal fabrika" (social factory) kavramı üzerinden tartışarak, geleneksel Marksist emek analizlerine sistemli bir eleştiri getirirler. "İş süreçlerinin fabrikadan topluma kaydığı" bir durumu anlatan sosyal fabrika (Negri, 1989: 92) tartışmasında beşeri iletişim, genel olarak üretimdeki el birliğinin temeli olarak görülür. Otonomistler, tarihsel olarak piyasanın dışında olduğu düşünülen ilgili pratikleri sermaye hesaplamalarına dahil eder. Christian Marazzi'ye göre (2011: 94), post-fordist çağda, hem işyerinin içindeki hem de dışındaki kolektif sosyal ilişkiler ve kişilerarası iletişim "canlı emekle birleşimi, canlı emeği üretken kılan sabit sermaye" haline gelir. Fabrikadaki ücretli emeğin devamı olarak iletişimsel davranışın egemen üretici güç olduğunu ifade eden Paolo Virno (2013: 67), dilbilimsel-bilişsel yeteneklerin enformasyon endüstrisinde üretim araçları olarak "toplam kalite" söylemiyle işlediğini ve bunun geleneksel örgütlü elbirliğinin yerini aldığı görüşündedir. Bu noktada Maurizio Lazzarato'nun (1996: 133) "gayri maddi emek" (immaterial labour) kavramı, enformasyon ekonomilerinin yatay ama hiyerarşik emek konumlarını anlamak için anlamlı bir uğraktır. Gayri maddi emek; bir taraftan metanın "enformasyonel içeriği”yle ilişkili olarak, sibernetik ve bilgisayar kontrolünü içeren becerilerin işçilerin emek süreçlerine etkilerine doğrudan atıfta bulunurken, diğer taraftan malların "kültürel içeriği”ni üreten etkinliklerle ilgili olarak, normalde "çalışma" olarak görülmeyen bir dizi etkinliği içeriyor. Diğer bir değişle; kültürel ve sanatsal standartları, modayı, zevkleri, tüketici normlarını ve kamuoyunu belirleme ve sabitlemeyi içeren etkinlikler gayri maddi emek biçimleridir. Dolayısıyla, gelişkin becerilere sahip çalışanlarla sınırlı 
olmayan gayri maddi emek, Lazzarato'nun ısrarla altını çizdiği gibi (1996: 136), günümüz endüstri sonrası toplumda üretken her öznenin bir etkinlik biçimi olarak ortaya çıkar.

Otonomistlerin post-endüstriyel üretim süreçlerini açıklamak için başvurdukları temel kavramlarından biri, Marx'ın Grundrisse'deki otomasyon analizlerinden devşirilen “genel zeka”dır. Marx Grundrisse'de (1993: 693), otomosyonun emeği "mekanik sistemin sayısız noktasındaki birbirinden ayrı canlı işçiler arasına dağılmış bilinçli bir organa" nasıl dönüştürdüğünü anlatır. İşçilerin bilinçlerinin toplamının makinelerde ve bu makinelerin çıktılarında nesnelleştirildiğini anlatan Marx’a göre, nesnelleştirilmiş emek canlı emeği, sadece kendine mal ederek değil, gerçek üretim sürecinde aktif bir şekilde tüketerek ve iktidar gücü olarak karşılar. Keza, "Sosyal beynin genel üretici güçlerinin bilgi ve beceri birikimi, emeğin aksine sermayeye emilir ve dolayısıyla sermayenin bir niteliği olarak ortaya çıkar” (1993: 694). Marx'ın analizlerini, "toplumsal üretimin direği haline gelmiş soyut düşünce" şeklinde karşılayan otonomistlere göre genel zeka; ${ }^{2}$ iş süreçlerinin fabrikadan topluma kaydığı günümüz toplumunda bireylerin iletişimsel yeteneğiyle aynı şeydir (Virno, 2013: 7273). Şöyle ki, işleyiş mekanizması tekilliklerin iletişimsel yeteneğine bağlı olan internet ağı ve dijital platformlar günümüzün en son makineleri olarak ele alınırsa, post-fordist çağın canlı işçisinin/kullanıcısının icracı potansiyeli genel zekadır. Metalaşmış kullanıcı faaliyetiyle bir ağa dönüşebilen internet giderek bilinçli bir organizma vasfı edinir. Bu bir taraftan, Marx'ın ifadesiyle (1993: 706) "genel sosyal bilginin ne ölçüde doğrudan bir üretim gücü haline geldiğini” (vurgu orijinal) gösterirken, diğer taraftan genel zekanın canlı emeğin değil, dijital teknolojinin bir niteliği olarak tecessüm etmesine yol açar. Gündelik karşılaşmalarda sıklıkla “Google’a sor” dediğimizde teyit ettiğimiz, emeğin nesnelleştirilmesidir.

Marx, insan türünün kendini gerçekleştirmesinin, yalnızca üretim araçlarının ve ürünlerinin ortak mülkiyetinin gömülü olduğu kolektif süreçlerle mümkün olduğunu

\footnotetext{
2 Otonomistler esasen "genel zeka”yı eşzamanlı bir ikilik içinde kavrar. Genel zeka, küresel kapitalizmin üretici organıdır ama aynı zamanda bilginin serbest akışıyla direnişi ve dolayısıyla toplumsal yaşamın yeniden icadının olası imkanlarını da mümkün kılar. Sınıfsal ilişsilerden türetilen ancak politik bir bütüne veya tekilliğe indirgenemeyecek (sınıf, kültür, cins etnisite vb.) farklılıkların dertlerinin ortaklaşmasını ifade eden "çokluk" (multitude) fenomeni, potansiyel direnişin otonom zeminidir. Teknolojik değişimden azade olmuş otonom emek, toplumu dönüştürücü bir etkinliği gerçekleştirebilir (Hardt ve Negri, 2004).
} 
söyler. Bu açıdan, ağa bağlı bilgi kooperatif üretim süreçlerinin toplamıdır ancak bilgi ve kullanıcı verileri meta mantığını içkin mülkiyet rejimine gömülüdür. Değişim-değeri bilginin ilksel özelliği haline geldiğinde, kullanıcılar bilgi süreçlerine ve ürünlerine yabancılaşırlar. Kullanıcı faaliyetinin metalaştırılması, Marksist siyasete göre, bireyleri kendi sosyal etkileşimlerinden, ürünlerinden ve süreçlerinden uzaklaştırırken, aynı zamanda onların alternatif, daha az sömürücü sosyal ilişkilere dayanan alt etkinlikler oluşturup sürdürmelerini de öteler (Jarrett, 2016: 94).

Özetle, kapitalist birikimin genişletilmiş mülksüzleştirme ve yabancılaştırma alanı olarak sosyal fabrika tartışmasında vurgulanan; post-fordist esnek düzende sömürünün dijital ekonomilerin bilgiye dayalı endüstriyel alanlarına doğru giderek genişlediğidir. Aynı zamanda, emek ile istihdamın aynı şey olduğu bilgisini dışlayan bu tartışma, istihdam dışı emeği hakir gören dışlayıcı baskın işsizlik söylemini de reddeder. Ücret formalitesinden taşan emek tartışması, uyrukların üretken etkinliklerinin enformasyon endüstrisi için önemini vurgularken; kullanıcıların dijital medya endüstrilerinin birikim süreçlerine hangi yollarla ve nasıl entegre olduklarının detaylı analizini gerekli kılıyor.

\section{Kullanıcı Emeği ve Deneyimin Müsaderesi}

Medya çalışmalarında, üretken özne olarak kullanıcı/izleyici tartışması yeni değil. Dallas W. Smythe (1977), görece erken bir tarihte, "izleyici emeği” (audience labour) kavramılla sermaye birikim rejiminin televizyon reklamları üzerinden toplumsal yeniden üretimini tartıştı. İzlemenin üretken bir faaliyet olduğunu söyleyen Smythe'e göre, reklam destekli medya izleyicileri, meta yaratan ancak ücreti ödenmeyen işçilerdir. İş dışı zamanın en uzun kısmı, izleyicilerin tek blok halinde reklam verenlere satılan zamanıdır. İzleyici emeği, reklamı yapılan mallara talebi yaratırken, medyayı tüketerek kendi emek gücünü yeniden üretir. Günümüz teknolojisinin televizyonun ötesine geçen gelişim hızı ve dijital ekonominin hacmi düşünüldüğünde ise, üretken özneler olarak medya kullanıcılarının gayri maddi emek piyasalarına katılımlarının daha çeşitli ve hesaplanabilir yollarla gerçekleştiğini söylemek mümkün.

Dijital medya endüstrisinin gayri maddi emek piyasasını Tiziana Terranova (2000: 34), "ücretsiz emek" (free labour) kavramı ekseninde tartışır. Terranova'ya göre internetin genişlemesi; işgücünün esnekliğinin artması, sürekli yetenek edinme çabası, 
serbest çalışma ve ofisten eve iş getirme gibi çağdaş eğilimlere ideolojik ve materyal dayanak sağlar. Dijital ekonomiyi destekleyen kültürel, teknik ve yaratıcı post-fordist çalışma süreçleri, geleneksel çalışan sınıfın geçerliliğini yitirmesine yol açmakla kalmaz, aynı zamanda anlamlı metaların aktif tüketicileri olarak konumlandırılan emekçi nesiller de üretir. Ücretsiz emek; inşa edilen bu "bilinçli" tüketimin keyifle benimsenen üretim etkinliklerine dönüştürüldüğü ama aynı zamanda "utanmazca sömürüldüğü” bir durumu anlatır (Terranova, 2000: 37). Beri taraftan Smythe ile paralel bir hatta tartışmayı sürdüren Christian Fucsh (2014), internet kullanıcılarının reklamlardan elde edilen gelir kaynaklı bir sektörün üretici güçleri olduğunu söyler. Fucsh (2014: 246), eğer internet platformları tarafından üretilen mal kullanıcı verisiyse, "o zaman bu verilerin oluşum süreci değer yaratan emek olarak görülmeli" görüşündedir. Ücret almayan kullanıcılar tarafından platformlara girilen verilerden devşirilen malların bütünüyle artık değer olduğunu söyleyen Fucsh, kullanıcının emeğini bu açıdan köle emeğine benzetir. Boş zamanın sosyal medya kullanımı üzerinden ticarileştirilme süreçlerine odaklanan Yeşim Akmeraner de (2018) her an ulaşılabilir olmanın her anı verimli bir faaliyete dönüştürdüğünü vurgulamaktadır. Akmeraner'e göre, sosyal medyadaki yaratıcı etkinliği temellük eden sermaye, emeğin öznelliklerini kendine tabi kılar.

"Tüketici emeği” (consumer labour) kavramıyla sosyal fabrika tartışmasına katılan Kylie Jarrett (2016; 2019) ise, meseleyi Marksist feminist bir yaklaşımla inceler. Müsadere edilen ve yabancılaştırılan kültürel ürünlerin dijital platformlara yüklenmesinin sayısız yoluna işaret eden Jarrett, bu verilerin aynı zamanda dijital medya şirketleri için artı-değer üretiminin temel taşı olduğunu vurgular. Jarrett isabetli çalışmasında, tüketici emeğinin Marksist feministler tarafından kavramsallaştırılan "ev içi emek" (domestic labour) ile kesişmesine dikkat çeker. Jarrett, üreten ve yeniden üreten kapasitesiyle ev içi emeğin, dışında görüldüğü kapitalist dinamiklerle ayrılmaz bir bütün olduğunun altını çizer. Ev içi emek, kültürel ve ekonomik olanı birleştiren emektir ve bir beden eğitim başarısına dayanır. Tam da bu nedenle ev içi emek, aynı bedensel eğitim başarısı gösteren dijital emek biçimlerini anlamak için bir yöntem sağlar (2019: 104). Ticari dijital medya sisteminin kullanıcı verilerini toplama mekanizmalarıyla doyurulduğunu belirten Jarrett (2016: 83), bu sistemin neredeyse tamamen tüketici emeği alanlarından oluştuğu görüşünü dile getirmektedir. Bu veriler; 
arama terimleri, durum güncellemeleri, "beğenme" veya "takip etme" gibi kişiselleştirme seçeneklerinden, kullanıcının belirli bir sitede kalış süresini ölçen tıklama akışı gibi girdilerden, önbellekleri izleyen yazılım sistemlerinden veya kullanıcıların coğrafi konumunu tespit eden IP adreslerinden vb. sağlanır.

Yukarıdaki tartışmanın gösterdiği gibi, dijital ekonominin kritik kavramı "veri”dir. Kavram, şaşırtıcı olmayan bir şekilde, bir el marifeti olan "vermek" fiilinden türetilmiştir. Verinin "data" olan İngilizce karşılığı da benzer şekilde "verilen" (that is given) anlamına gelen Latince "datum" kelimesinin çoğuludur.

Medya araştırmalarında bir çalışma alanı olarak ortaya çıkan "büyük veri” (big data) dijital dönüşüm analizlerinde başvuru temalarındandır (Fuchs ve Chandler, 2019). Büyük veriyle ilgili çalışmalar, algoritmik dijital dönüşüm aşamalarından bilginin; ekonomiyi, siyaseti, kültürü ve çevreyi nasıl dönüştürdüğünü ele alıyor. The Economist, Mayıs 2017'deki ön kapağında “Dünyanın En Değerli Kaynağı” başlığıyla “büyük veri”yi (big data) petrole benzetiyordu. "20. yüzyıl başlarında dünya ekonomisi ve toplumsal dönüşüm için petrol ne ise 21. yüzyılda da veri odur" diyen The Economiste göre (2017), yenilikçi ve yaratıcı olanaklara yol açan büyük veri, bilgi üretmede yeni yollar sağlıyor. Birleşmiş Milletler de, büyük veri analitiğinin, gıda sıkıntısından çatışmalara ve çevresel krizlere kadar dünyanın en acil sorunlarını çözmek için merkezi önemde olduğunu (United Nations, 2014) bildiriyordu. Bu açıklamalar Evgeny Morozov'un (2019), yeni bir düşünce zincirinin, küresel ekonominin dijital yenilikler etrafında bir çeşit adalet modeli oluşturarak nasıl yeniden tasarlanabileceğini ele aldığına yönelik uyarısına dikkati çekiyor.

Viktor Mayer-Schönberger ve Thomas Ramge'nin (2018) "veri kapitalizmi” (data capitalism), Shoshana Zuboff'un (2015) “gözetim kapitalizmi” (surveillance capitalism) dediği "büyük veri”nin net bir tanımı bulunmuyor. Ancak büyük veri denince, hacim, çeşitlilik ve hız anlaşılmakta (Kitchin 2014: 68). Örneğin, Google, Facebook, Amazon, gözetim kameralar sistemi, fiyat ve ekonomik veri araçları, e-devlet uygulamaları büyük veri kümeleridir. Bunlar hacim olarak öylesine büyüktür ki, insanlar tarafından işlenip analiz edilmesi mümkün değildir. Gerçek zamanlı ve çok yüksek hızlarda üretilen büyük veri ancak dijital makine güdümlü algoritmalar tarafından işlenip analiz edilebilir. Büyük veriyi, teknolojik bir nesne, etki ya da yetenek olarak görmemek gerektiğine dikkat çeken Zuboff (2015: 75), büyük verinin toplumsal bir süreç olduğunun altını 
çizer. Ona göre büyük veri, enformasyon kapitalizminin gelir ve piyasa kontrolünü sağlama aracı olarak insan davranışını tahmin etmeyi ve değiştirmeyi amaçlayan bir birikim mantığıdır.

\section{Bir Sürgün Deneyimi: Mobil “Özerklik”}

Teknik altyapısı ve elde tutulan dünya deneyimini içkin hegemonyasıyla mobil telefon, iletişimsel yeteneklerin toptan kamusallık kazandığı bir toplumsal durumu anlatır. Yazılım marifetiyle kişinin kredi kartı, kimliği, uçak bileti, ev anahtarı, parmak izi, otomobil kontağı, imzası, mahremiyeti, kamusal varlığı, işi yeri vb. olabilen mobil telefon aynı zamanda tüm bunları envaiçeşit yöntemle koruma altına aldığını iddia eden benzersiz bir dijital makinadır. Belli talepler eşliğinde intiyaç duyulan kimi uzmanlıkların ve nesnelerin, etkinlik veya işlevlerini dijitalleştirerek elimize aktaran bu alet, insanlarla ve nesnelerle ilişkimizde kompakt bir deneyimi örgütler. Kişiyi tanıtan, ayıran, dahil eden ya da temsil eden elin bu kompakt etkinliği, kendi kendimizin efendisi olabileceğimiz yanılsamasını yeniden üretir. Bu deneyimin içsel tutarlılığı, eldeki telefonun kuşku götürmez bireyselliğinden devşirilir. "El koymak” değiminin altını çizdiği gibi, sahiplik fikrinin temel gösterenidir el (Leader, 2016). Teknolojik dolayımla elde edilen yanılsamalı özerklik, seçmenin bir zorunluluk olduğu modern özgürlük fikrinin paradoksudur. Leader'in "özerklik bağımlıığı" dediği yanılsamalı toplumsal inşa, küresel markaların da motivasyonudur. Şirketler pazarlama stratejileriyle, içimizdeki "benzersiz", "yaratıcı”, "kendine yeten” bireyi keşfetmemiz için elinden geleni yapar. Bu telkin, her yeni modelde veya güncellemede farklı fırsatlarla tetiklenir. Dijital telefonla birlikte benzersizlik ve yaratıcılık, hiç olmadığı kadar erişilebilir bir tedarike dönüşürken; kişiye çeşitli ağlar üzerinden bu talebini teyit ettirebileceği bir görünürlük ve performans alanı da sağlanır. Öte yandan, dijital ekranla temasta kimliğin teyidi zorunludur. Her mobil telefon, kullanıcının kimlik verisini içeren bir numaraya bağlıdır çünkü. Bu açıdan mobil telefon, kullanıcının iradi anonimleşme taleplerine diğer bilgisayar veya bilgisayar özelliğine sahip cihazlardan daha kapalı bir sisteme sahiptir. Harf ve rakamlardan oluşan dijital varlığımızın türdeş çıktılar üreten türdeş temasları, paradoksal olarak, özerklik talebinin yeniden üretildiği "kişiselleştirilmiş" mobil telefondan elde edilir. Her biri dijital bir numaraya bağlı ve bu yüzden her biri bir 
kullanıcı demek olan mobil telefonun bu şahsiliği; daha isabetli hedefler belirlenmesinde piyasa araştırmalarına ideal veri toplama koşulları yaratır.

Guy Debord (2014) meta haline gelmiş insan iletişimi olarak "gösteri"den söz ettiğinde, deneyimin şeyleşmesine vurgu yapıyordu. İletişim metasının pek çok endüstriyel sektör için kritik önemine işaret eden Castells de (2008: 25, 281), "ileri ekonomilerin özelliği olan bilgisayar yazılımı, video üretimi, mikro-elektronik tasarımı, biyo-teknolojiye dayalı tarım ve başka birçok kritik süreç, bilgi içeriklerini ürünün somut varlığıyla öyle ayrılamaz derecede birleştirdiler ki, 'mallar' ve 'hizmetler' arasındaki sınırları seçmek imkânsızlaştı” der. Dijital platformlardaki memnuniyet puanları, yorum, beğeni veya şikayet iletileri; kurutma makinası, akşam yemeği, otomobil, şampuan, bahçe çiti, yaz tatili veya keçi peyniri hakkında malumat edinilen iletişim metalarıdır. Metaların nesnelerden göstergelere dönüştüğü dijital platformlardaki içeriklerde, materyal varlıklarıyla temas edilmese de mallara dair bir karşılaşma sahnelenir. Bizleri malların özelliklerine ve kullanım bilgisine muttali kılan bu sahne, piyasa tarafından anlamlandırılan göstergelerin enflasyonist istikrarsızlığı nedeniyle devamlı surette yeniden kurulur. Tüketim aktivitelerini ara yüzler oluşturarak biçimlendiren dijital ekran böylece, sadece enformasyon değil, ürünlerin materyal gerçekliğine dair deneyim de vaat eder. Farklı somut varlıkları, elin ekran üzerindeki türdeş hareketleriyle kavrayan bu deneyimin gerçeklik düzeyi, kişinin ürünle materyal karşılaşmasını "selfie" ya da "kullanıcı yorumu" yoluyla dijitalleştirilmesiyle de test edilir. Özetle deneyim, genişletilmiş piyasalar sistemi içinde "özgün” uğraklar oluşturabiliyor. Günümüzde bunu ifade eden en uygun kullanım kuşkusuz "beta sürüm"dür. Beta sürüm, "bitmemiş" yeni kültür teknolojisinin "deneme" süreci sonunda nihai biçim almasını amaçlayan bir pazarlama stratejisine dayanır. Anonim kullanıcılar, dijital ekrana temas etmek suretiyle, söz konusu icadın/ürünün rekabet yeteneklerini geliştirecek bilgiyi üretmek için elbirliği ederler. Kapitalist emek sözleşmesine binaen fabrikada bir arada bulunan ücretli işçilerinkinden farklı bir elbirliği deneyimidir bu. Burada söz konusu olan, örgütlü bir kamusallık değil, pazarın intiyaçları doğrultusunda davranışsal veriye dönüştürülüp müsadere edilen, anonim kullanım istatistikleridir.

Her gün milyarlarca el, hiçbir emek sözleşmesine dahil olmaksızın, dijital makineyle temas ederek bilgi ekonomilerinin oluşmasını sağlıyor. Biz telefonu kullanırken burada birikmeye başlayan, sadece müsadere edilen davranışsal veriler 
değil, aynı zamanda haklardır. Günlük uyku saatinden adım sayısına, içilen kahveden izlenen filme kadar, pek çok gündelik karşılaşmayı ve faaliyeti gönüllü bir şekilde dijitalleştiren işleviyle el, her an her yerde izlenebilmenin koşullarını da yaratıyor. Zuboff (2019: 45), kendi davranışlarımızın sürgünleri olduğumuzu söylediğinde, dijital etkinliğimizden devşirilen ve başkaları tarafından el konulan bilgi üzerinde hiçbir erişim veya denetim hakkımız olmadığını ifade ediyor. "Akılı" veya "kişiselleştirilmiş" sözcüğüyle başlayan neredeyse her ürün ve hizmetin veya internete bağlı her cihazın "gözetim ekonomisi” için veri tedarik zincirinde bir ara yüz olduğunu belirten Zuboff'a göre, dijital teknoloji kendi bilgileştirme kapasitesi üzerinden, dünyayı sürekli verilere dönüştürerek yeni bilgi alanları yaratıyor ve ardından bunu siyasi ve ekonomik rekabetin konusu haline getiriyor. Kullanıcıların davranış verilerine dayanan imdb.com istatistikleri buna örnek gösterilebilir. Bu istatistikler, gündelik bir faaliyet olarak film izleme talebine dair karar verici genel kabullerin oluşmasında belirleyici bir rol oynarken, TV ve sinema endüstrisinin ürünlerini imdb.com listelerinin üst sıralarına taşıma rekabetini de tetikler.

Sonuç olarak, politik, ekonomik ve günlük yaşamın yeni anlayışlarını oluşturmayı amaçlayan dijitalleşme; insan iletişiminin aktörlerini, yapılarını, sistemlerini, içeriğini, etkilerini, bağlamlarını ve güç yapılarını değiştirmekte. Her an ulaşılabilir mesafedeki mobil telefon, dijital dönüşümün birikim paradigması doğrultusunda gerçekleşmesine imkan veren kilit önemde bir nesne/alettir. El ve beyin arasındaki ilişkide kullanıcının müzakereci yeteneklerini yerinden eden mobil telefon, birikim mantığını içkin meta piyasasının yönlendirdiği kompakt bir deneyimle, kullanıcı emeğini üretim süreçlerine katmakta. Tüketicinin enformel çalışana dönüştüğü bu sömürünün önceki biçimlerinden farkı, hiç olmadığı kadar geniş kitleleri kapsaması ve yukarıda belirtildiği gibi, bu kitlelerin hiçbir emek sözleşmesine dahil olmamasıdır. Yaşam alanlarına yönelik öznel ve nesnel verileri sermayeleştirilen insanlar, kavramaya çalıştıkça sürgünü oldukları bir dünya deneyiminin içine düşmekte.

\section{Sonuç}

Elimiz, hem çok intiyaç duyduğumuz, hem de hayatı manipüle ettiğimiz bir parçamız. Kapasitesini etkilediği öznenin hareket etme ve etkileşime geçme şeklini değiştiren 
mobil telefon; dünyayla temasta kuralları piyasa tarafından belirlenmiş bir el performansı varsayar. Devamlı surette güncellenen ve elin meşguliyetine rağmen, tutulan ama ele geçirilemeyen bu "dünya"; dijitalleşen bilginin demokratik değerler hilafına asimetrik yoğunlaşması şeklinde tecelli ediyor. Otoritenin risk haritaları oluşturmasını sağlayan dijital hareketleriyle her an izlenebilen yurttaşlar, şirketler tarafından tahmin edilebilir tüketim eğilimleri gösteren varoluşlar olarak görülmekteler. Piyasa güdümlü dijitalleşme, bireysel otonomiyi aşındıran, karar alma hakkını yerinden eden bir deneyim biçimini tetikliyor. Yurttaşlığın veriye indirgenmesine ve böylece eşitsizliğin derinleşmesine yol açan bu yönelimin geniş ölçekli bir anti-demokratik dalga içinden okunması; gözetim ve deneyim ilişkisinin otoritenin ve piyasanın birleşik çıkar mantığı içinden analizini gerektiriyor.

Bu çalışmanın teknoloji karşıtlığı gibi bir fikirden hareket etmediğinin altını çizmek isterim. Yukarıdaki tartışmadan da anlaşılacağı üzere, teknoloji her zaman insan kapasitesini etkiledi. Benzersiz ilişkilerle ortaya çıkan teknolojik nesne insan öznesinden ayrılamaz. Dolayısıyla buradaki tartışma, bir teori öne sürmekten ziyade, iletişim/kültür teknolojilerinin ortaya çıkardığı yeni toplumsal duruma içkin bir eğilimi vurgulama gayretine dayanıyor. Bu eğilim, hiçbir aletle kıyaslanmayacak ölçüde yaygın ve hiç olmadığı kadar elin meşguliyetine dayalı mobil telefon kullanımının esnek birikim rejiminin sömürü sınırlarını genişletiyor olmasıdır.

Bitirirken, dijitalleşmeye içkin paradoksal ikilikler etrafında sürdürülen görece kamusallık arz eden tartışmaların, dijital kullanımların baskın biçimlerine dair toplumsal kabullerin yerleşmesinde etkili olduğu söylenebilir. "Anonimlik" ve "özerklik" dijital temaslarda bir araya gelebilen paradoksal fenomenlerdir mesela. Bireysel endişenin "güvenlik duvarı" öneren gündelik yeniden üretimi ise tam olarak dijital evrenin "özgür" ortamlarında gerçekleşiyor. Demokrasi ve totalitarizm, dijitalleşmeyle ilgili bir tartışmanın vazgeçilmez kavram setidir. Akıllı teknolojilerin nimetleri ile yapay zekanın tehditleri kimi zaman çakışabiliyor. Özetle dijitalleşme, ağ ve benlik arasında karşıtığı yapılandırmak suretiyle risk uğrakları icat ediyor. Piyasa tarafından koşullanmış "dünyalılık” bilgisinin sınırları olan bu uğraklar, dijital deneyimin kozmopolitliği içinden anlamlandırılıyor.

Mobil telefonun aracılık ettiği, meta üzerinden de olsa, kozmopolit bir deneyimdir. Ancak bu kozmopolit deneyim, her zaman piyasaların arzuladığı bir yönde ve 
süreklilikte gerçekleşmeyebilir. Castells'in belirttiği gibi (2008: 6-8), kişiselleştirilmiş aygıtlara, interaktif iletişime, ağlar oluşturmaya, durup dinlenmeksizin yeni teknolojik atılımların peşinden koşmaya yapılan vurgu, şirketler dünyasının ihtiyat geleneğinin amaçlamadığı toplumsal sonuçlara da yol açabilmektedir. 2000'lerde Dünya Ticaret Örgütü protestolarının ya da 2010'larda “Arap Baharı” isyanlarının örgütlemesinde ve yayılmasında enformasyon teknolojilerinin oynadığı rol yadsınamaz. Günümüz toplumsal hareketlerine yön veren dijital ağlar, özellikle mobil telefonun kritik bir önemde olduğunu gösteriyor. Mobil telefon, kullanıcı öznenin itirazı doğrultusunda ağ oluşturma/ağa dahil olma girişimini ya da ağın taktik/stratejik karar ve manevralarının parçası olmasını temin edecek verilere ulaşma talebini tam da o hareket halindeyken gerçekleştirmesini sağlar. Bu noktada, protesto hareketlerini anlamlandırmaya çalışan analizler, dijital ağları alternatif siyasi örgütlenme ve kontrol biçimleriyle ilişkilendirme eğiliminde oldular. Örneğin, sömürüyü derinleştiren dijital kapitalizmin aynı zamanda kapitalizmin mantığını aşan otonom alemler için yeni alanlar yarattığı söyleyen Antonio Negri'ye göre (2017: 25), dijitalleşmeyle birlikte meta giderek daha şeffaf bir hale geliyor ve "sosyal işbirliğinin özerkliğine, proleter öznelerin öz-değerine giderek daha duyarlı iş kolları ortaya çıkmaya başlıyor." 


\section{Kaynakça}

Akmeraner, Yeşim (2018). "Digital Labour in Social Media: Expropriation of Leisure Time, Commercialization of Creative Activity and the Problem of Alienation." Kültür ve Illetişim, 21(42): 98-119.

Anderson, Benedict (2015). Hayali Cemaatler. Çev., İskender Savaşır. İstanbul: Metis. Arendt, Hannah (1998). The Human Condition. Chicago: University of Chicago Press. Barbrook, Richard (2002). "The Hi-Tech Gift Economy." Explorations in Media Ecology, 1(1): 31-40. doi: 10.1386/eme.1.1.31_1

Birgün (2019). “Uçuruma Yuvarlanan Kadın, Cep Telefonu Bulunmadan Kurtarılmak İstemedi." https://bit.ly/2K9WfWF Erişim tarihi: 10.11.2019.

Castells, Manuel (2008). Ağ Toplumunun Yükselişi. Çev., Ebru Kılıç. İstanbul: Bilgi.

Darwin, Charles (2004). The Descent of Man. James Moore ve Adrian Desmond (der.) içinde. Londra: Penguin.

Debord, Guy (2014). Gösteri Toplumu ve Yorumlar. Çev., Ayşen Ekmekçi ve Okşan Taşkent. İstanbul: Ayrıntı.

Ferraris, Maurizio (2014). Where Are You?: An Ontology of the Cell Phone. New York: Fordham University Press.

Fuchs, Christian (2014). Digital Labour and Karl Marx. Oxon: Routledge.

Fuchs, Christian ve David Chandler (2019). "Introduction Big Data Capitalism - Politics, Activism, and Theory." Digital Objects, Digital Subjects. David Chandler ve Christian Fuchs (der.) içinde. Londra: University of Westminster Press. 1-20. doi: 10.16997/book29.a

Hardt, Michael ve Antonio Negri (2004). Çokluk. Çev., Barış Yıldırım. İstanbul: Ayrıntı. Jarrett, Kylie (2016). Feminism, Labour and Digital Media: The Digital Housewife. New York: Routledge.

Jarrett, Kylie (2019). "Through the Reproductive Lens: Labour and Struggle at the Intersection of Culture and Economy." Digital Objects. Digital Subjects. David Chandler ve Christian Fuchs (der.) içinde. Londra: University of Westminster Press. 103-116.

Kitchin, Rob (2014). The Data Revolution: Big Data, Open Data, Data Infrastructures and their Consequences. Londra: Sage. 
Lazzarato, Maurizio (1996). "Immaterial Labor." Radical Thought in Italy: A Potential Politics. Paolo Virno ve Michael Hardt (der.) içinde. Minneapolis: University of Minnesota. 133-147.

Leader, Darian (2016). Hands: What We Do with Them - and Why. Londra: Penguin. Lukacs, Georg (1972). History and Class Consciousness. Cambrige: MIT.

Marazzi, Christian (2011). Capital and Affects: The Politics of the Language Economy.

Los Angeles: Semiotext(e).

Marx, Karl (1993). Grundrisse. Londra: Penguin.

Marx, Karl (1997). Kapital - Cilt 1. Çev., Alaattin Bilgi. Ankara: Sol Yayınları.

Mayer-Schönberger, Viktor ve Thomas Ramge (2018). Reinventing Capitalism in the Age of Big Data. New York: Henceforth, RC.

McLuhan, Marshall (2014). Gutenberg Galaksisi. Çev., Gül Çağalı Güven. İstanbul: YKY.

Mediatrend (2018). "Dünya Mobil Aksesuar Pazarı Trendleri” https://bit.ly/33AsF4o Erişim tarihi: 10.11.2019.

Morozov, Evgeny (2019). “Digital Socialism?” New Left Review, 116/117: 33-67.

Negri, Antonio (1989). The Politics of Subversion: A Manifesto for the Twenty-first Century. Cambridge: Polity.

Negri, Antonio (2017). Marx and Foucault. Cambridge: Polity.

Ong, Walter (1961). "Ramist Method and the Commercial Mind." Studies in the Renaissance 8: 155-172. doi:10.2307/2856994.

Özkan, Yusuf (2016). "Yoğun Tablet Bilgisayar ve Akıllı Telefon Kullanımı Çocuklar İçin Zararlı.” https://bbc.in/3bpW2dU Erişim tarihi:10.11.2019.

Sennett, Richard (2019). Zanaatkar. Çev., Melih Pakdemir. İstanbul: Metis.

Smythe, W. Dallas (1977). "Communications: Blindspot of Western Marxism." Canadian Journal of Political and Social Theory, 1(3): 1-27.

Terranova, Tiziana (2000) "Free Labor: Producing Culture for the Digital Economy." Social Text 63, 18(2): 33-58.

The Economist (2017) "Fuel of the Future." The Economist, Mayıs 2017: 14-17.

United Nations. (2014). A World That Counts: Mobilising the Data Revolution for Sustainable Development: Report Prepared at the Request of the United Nations Secretary-General. Cenova: UN. 
Virno, Paolo (2013). Çokluğun Grameri. Çev., Volkan Kocagül ve Münevver Çelik. İstanbul: Otonom.

Zuboff, Shoshana (2015). "Big Other: Surveillance Capitalism and the Prospects of an Information Civilization." Journal of Information Technology, 30(1): 75-89. doi: 10.1057/jit.2015.5

Zuboff, Shoshana (2019). "Kişisel Olanın Sömürgeci Fethi.” Express Dergisi, 168: 4447. 